\title{
Water quality in the littoral zone of the Barguzin and Chivyrkuy bays in the summer of 2019
}

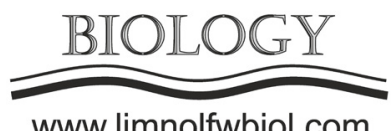

www.limnolfwbiol.com

\author{
Sakirko M.V. ${ }^{*}$, Domysheva V.M. ${ }^{1}$, Panchenko M.V. ${ }^{2}$, Pestunov D.A. ${ }^{2}$, Shamrin A.M. ${ }^{2}$ \\ ${ }^{1}$ Limnological Institute, Siberian Branch of the Russian Academy of Sciences, Ulan-Batorskaya Str., 3, Irkutsk, 664033, Russia \\ ${ }^{2}$ V.E. Zuev Institute of Atmospheric Optics. Siberian Branch, Russian Academy of Science (IAO SB RAS), Academician Zuev Square Str., 1, \\ Tomsk 634055, Russia
}

\begin{abstract}
Currently, with an increase in technological progress, anthropogenic impact on the environment is increasingly apparent. Since surface waters are the most vulnerable part of the natural environment, a detailed study of water pollution is one of the urgent tasks. This article presents the results of the instrumental measurements and the assessment of the pollution of the surface waters in the littoral zone of the Barguzin and Chivyrkuy bays of Lake Baikal. To determine the degree of water pollution, we compared hydrochemical indicators with the standards of the maximum permissible concentrations. We revealed that in different parts of the Chivyrkuy Bay, water quality varies in a wide range from slightly polluted to very polluted and, in some cases, highly polluted. The waters in the Barguzin Bay can mainly be classified as slightly polluted, and only in some areas - as moderately polluted or highly polluted. According to the comprehensive water pollution index, the waters in the Chivyrkuy and Barguzin bays is assessed as conditionally polluted and conditionally pure, respectively.
\end{abstract}

Keywords: Chivyrkuy Bay, Barguzin Bay, Lake Baikal, water quality, nutrients, nitrogen, phosphorus, silica, organic matter, chlorophyll $a$

\section{Introduction}

Barguzin and Chivyrkuy are the largest bays of Lake Baikal, with an area of 725 and $300 \mathrm{~km}^{2}$, respectively. They are located on the east coast of Lake Baikal and separated by the Svyatoy Nos Peninsula. The Barguzin valley adjacent to the bay and coves of the Chivyrkuy Bay are known for their mineral springs and attractive to many tourists. All this leads to an increase in anthropogenic pressure on coastal ecosystems and, consequently, ecological problems.

Recent studies have shown that the main problem of Lake Baikal is continuing eutrophication of coastal waters and annual mass development of spirogyra and potentially toxic cyanobacteria that may have a toxic effect on fish and other hydrobionts (Kravtsova et al., 2012; 2014; Timoshkin et al., 2016). In the future, this situation may also occur in the deep part of Lake Baikal.

This study aims to assess the water quality in the Barguzin and Chivyrkuy bays based on the data on the chemical composition of water in the littoral zone.

\section{Material and methods}

Hydrochemical investigations were carried out in August 2019 on the Barguzin River, at eight stations in the Barguzin Bay and nine stations in the Chivyrkuy
Bay (Fig. 1). Sampling was carried out at the locations of settlements, mass recreation of tourists, mooring of ships, the confluence of rivers as well as background coastal areas and in the central parts of the bays. At the central station in the Barguzin Bay, the depth was $150 \mathrm{~m}$; in the Chivyrkuy Bay - $5 \mathrm{~m}$. To compare the data obtained in the central part of the bays with the coastal ones, the depths of 0 and $5 \mathrm{~m}$ were used. At each station, samples were taken from the water edge and surface as well as at the bottom at a distance from the coast where the depth was $5 \mathrm{~m}$.

For chemical analyses, certified methods were used. Immediately after collection, $\mathrm{pH}$ (regulatory guide RD 52.24.495-2017, 2017) and dissolved oxygen (regulatory guide RD 52.24.419-2005, 2004) were measured in samples. The primary production and destruction of organic matter were determined by the light and dark bottle method (Rukovodstvo..., 1983).

To determine nutrient concentrations, samples were filtered through a membrane filter with a pore size of $0.45 \mu \mathrm{m}$. The silica concentrations were determined by the photometric method in a yellow form of molybdosilic acid (regulatory guide RD 52.24.433-2005, 2005). Spectrophotometrically, nitrite ions were determined with Griess reagent (national standard GOST 33045-2014, 2019), ammonium ions

*Corresponding author.

E-mail address: sakira@lin.irk.ru (M.V. Sakirko) 
- by the indophenol method (regulatory guide RD 52.24.383-2018, 2018), nitrate ions - using sodium salicylate (national standard GOST 33045-2014, 2019), phosphate ions - with the formation of phosphorus molybdenum blue (national standard GOST 18309$2014,2015)$. The concentration of the total phosphorus was determined after conversion of organically bound phosphorus compounds to orthophosphate through high-temperature persulfate oxidation (national standard GOST 18309-2014, 2015).

Chemical oxygen demand (COD) determined by dichromate oxidation (federal environmental regulation PND F 14.1:2:4.190-03, 2007), biochemical oxygen demand (BOD5) (regulatory guide RD 52.24.420-2006, 2006) and permanganate oxidation (federal environmental regulation PND F 14.1:2:4.15499,2012 ) served as indirect indicators of the organic matter content.

The chlorophyll a concentration, a photosynthetic pigment characterizing a degree of phytoplankton development, was determined by the spectrophotometric method after acetone extraction (national standard GOST 17.1.4.02-90, 2010).

\section{Results and discussion}

\section{Barguzin Bay}

On the coast of the Barguzin Bay, there are settlements Ust-Barguzin and Maksimikha, in $7 \mathrm{~km}$ from which the Rovesnik sports and recreation camp hosts over 500 people annually.

In the littoral zone of the Barguzin Bay, there are mostly sandy soils, and only on the coast of the Svyatoy Nos Peninsula, beaches are rocky. A feature of the northeastern part of the bay is the influx of the waters from the Barguzin River, which spread along the coasts of the bay (Tomberg et al., 2019). Agricultural production, including irrigation farming, is developed in the basin of the Barguzin River. The water temperature in the river during the study period was $20^{\circ} \mathrm{C}$. Water in the Barguzin River was enriched with silica, with a concentration of $3.8 \mathrm{mg} / \mathrm{L}$. Among the mineral nitrogen compounds, there were nitrate ions in the concentration of $0.15 \mathrm{mg} / \mathrm{L}$ and nitrite ions in trace amounts; ammonium ions were not found. The concentration of mineral (phosphate) phosphorus in

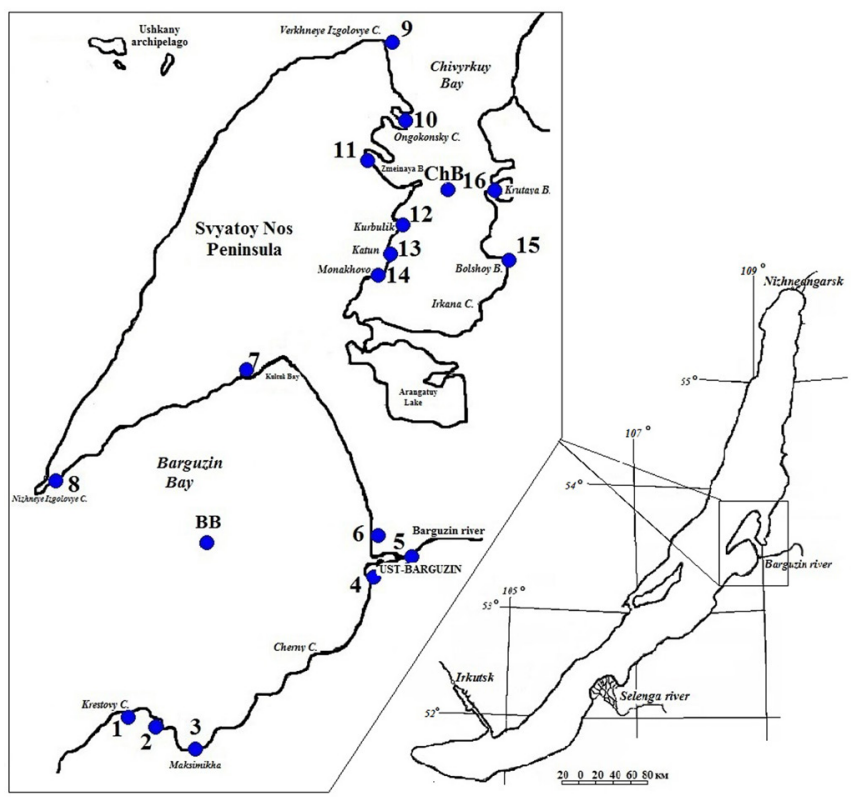

Fig. 1. Map of sampling stations in the Barguzin Bay and Chivyrkuy Bay, Lake Baikal.

the water of the Barguzin River was $17 \mu \mathrm{g} / \mathrm{L}$, and the total phosphorus - up to $41 \mu \mathrm{g} / \mathrm{L}$ (Fig. 2). COD was at the level of $10.6 \mathrm{mgO} / \mathrm{L}$.

In the littoral zone of the Barguzin Bay, during the study period, the water temperature reached 22.5 ${ }^{\circ} \mathrm{C}$ (station 2); near Krestovy Cape (station 1) at a depth of $5 \mathrm{~m}-14.5{ }^{\circ} \mathrm{C}$. In the central part of the bay the temperature on the surface was $14 .{ }^{\circ} \mathrm{C}$, and in the near-bottom area, at a depth of $150 \mathrm{~m},-3.8^{\circ} \mathrm{C}$.

The $\mathrm{pH}$ in the coastal waters ranged from 8.89 to $7.93 \mathrm{pH}$ units, which indicates the intensive photosynthetic processes. In $7 \mathrm{~km}$ from the termination of the Kultuk Bay (station 7), the water edge zone is separated by a shingle spit and, hence, the water exchange is reduced, which affected the chemical composition of the water. Here, we recorded the minimum $\mathrm{pH}$ and low oxygen concentration (7.96 $\mathrm{mg} / \mathrm{L})$. In the centre of the bay, $\mathrm{pH}-8,50$ units, and the concentration of the dissolved oxygen was $9.6 \mathrm{mg} / \mathrm{L}$.

The minimum concentration of the dissolved oxygen of $8.8 \mathrm{mg} / \mathrm{L}$ was observed at the station 4 (near the Barguzin River estuary), and the maximum concentration of $10.6 \mathrm{mg} / \mathrm{L}$ - in the water edge near
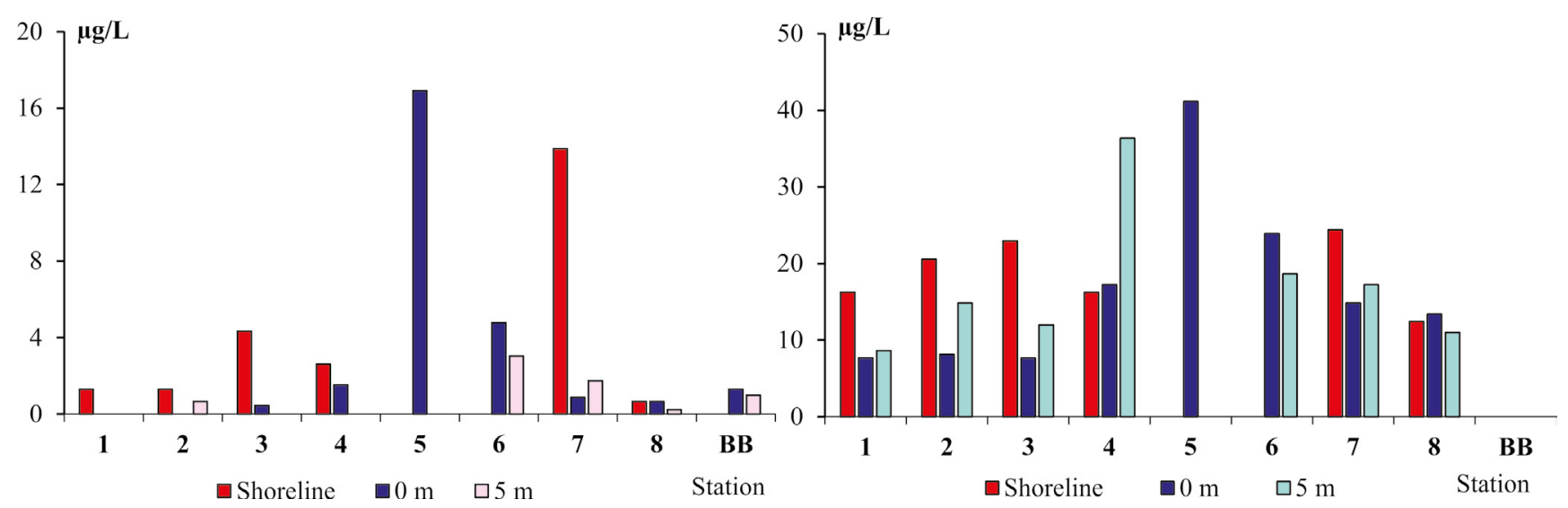

Fig. 2. Distribution of the concentrations of mineral (A) and total (B) phosphorus in the Barguzin Bay, August 2019. 
the Rovesnik camp. Notably, the percentage of water saturation with oxygen at all stations was higher than $100 \%$; the maximum water saturation was also recorded at the station near the camp.

The concentration of nutrients is the important indicator of the trophic state and quality of the coastal waters. Anthropogenic enrichment of waters with nutrients may lead to a radical restructuring of the aquatic ecosystem. The ion concentrations of ammonium and nitrites in the coastal waters of the Barguzin Bay was low (below $0.003 \mathrm{mg} / \mathrm{L}$ of nitrites and $0.01 \mathrm{mg} / \mathrm{L}$ of ammonium); nitrates were less than $0.10 \mathrm{mg} / \mathrm{L}$. Phosphorus, the high concentration of which leads to eutrophication, affects strongly the productivity of water bodies. Measurements have shown that the amount of mineral phosphorus in the littoral zone does not exceed $5 \mu \mathrm{g} / \mathrm{L}$. The concentration of the total phosphorus varies from 8 to $36 \mu \mathrm{g} / \mathrm{L}$, and in the water edge zone, it is significantly greater than at a distance from the coast (Fig. 2). The maximum record of the total phosphorus was in the near-bottom area, in one $\mathrm{km}$ to the left of the Barguzin River estuary (station 4), which is associated with the influx of the river waters there. At station 7, the isolation of the water edge zone affected not only low oxygen concentration and $\mathrm{pH}$ but also an increase in the mineral phosphorus. In the centre of the bay, in the surface water layer, the concentration of mineral phosphorus was $1.3 \mu \mathrm{g} / \mathrm{L}$.

The average concentration of silica in the bay was $0.7 \mathrm{mg} / \mathrm{L}$; high concentration of up to $1.9 \mathrm{mg} / \mathrm{L}$ was observed at a one-km distance and to the right from the Barguzin River estuary, which is due to the influx of the river waters there, in which the silica concentration is $3.8 \mathrm{mg} / \mathrm{L}$.

Chlorophyll a serves as a criterion in assessing phytoplankton biomass and its production, determining the quality of natural waters and the level of eutrophication of water bodies. The distribution of chlorophyll $a$ in the coastal zone of the Barguzin Bay is uneven (Fig. 3). The water edge zone in the southern part of the bay (stations 1-3) is significantly distinguished by the amount of chlorophyll $a$. According to the previous studies (Tomberg et al., 2012; Timoshkin et al., 2016), there are large coastal accumulations of detritus in these areas, indicating an intensive development of phytobenthos in summer.

\section{Chivyrkuy Bay}

Chivyrkuy is the Baikal bay that runs the farthest inland; its length is approximately $25 \mathrm{~km}$. The east and west coasts form a series of small and well-sheltered coves with a depth of approximately $5 \mathrm{~m}$ where the bottom of coasts and beaches are mostly sandy. On the west coast of the Chivyrkuy Bay, there are three main settlements: Katun, Kurbulik and Monakhovo. The bay places several hot springs, the most famous and visited of them is the Zmeiny spring on the west coast in the cove of the same name.

The coastal water of the Chivyrkuy Bay warms up well, and during the study period, the temperature in the littoral zone reached $20.5^{\circ} \mathrm{C}$; in the centre of the bay, the water temperature was $18.6{ }^{\circ} \mathrm{C}$ on the surface

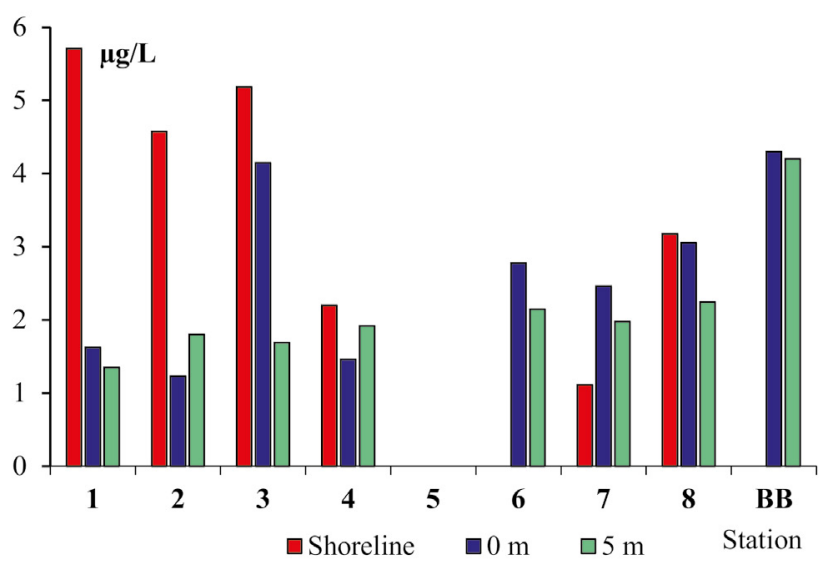

Fig. 3. Distribution of the chlorophyll $a$ concentrations in the Barguzin Bay, August 2019.

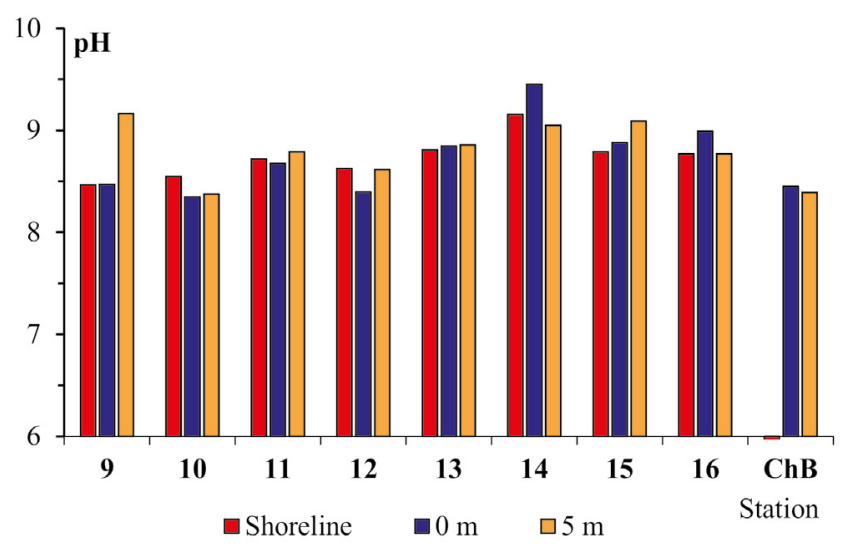

Fig. 4. Distribution of $\mathrm{pH}$ by stations in the Chivyrkuy Bay, August 2019.

and $14.6{ }^{\circ} \mathrm{C}$ in the near-bottom area. It is worth noting that, unlike the Barguzin Bay, $\mathrm{pH}$ was higher there. The maximum $\mathrm{pH}-9.45$ was recorded at the bottom near the Monakhovo settlement (station 14) (Fig. 4), and the minimum (8.36 units) - in the centre of the Ongokon cove, and at the bottom, $\mathrm{pH}$ was 8.45 units.

The concentration of dissolved oxygen averaged $9.5 \mathrm{mg} / \mathrm{L}$; the maximum value of 7.56 was recorded at the water edge near the Monakhovo settlement (station 14 ), and the average oxygen saturation of water was $140 \%$.

In the coastal waters of the Chivyrkuy Bay, the concentration of the mineral phosphorus, like in the Barguzin Bay, generally, does not exceed $5 \mu \mathrm{g} / \mathrm{L}$; high concentration of $21 \mu \mathrm{g} / \mathrm{L}$ was only near the Monakhovo settlement (station 14) (Fig. 5A). The concentrations of the total phosphorus varied over a wide range from 11 to $182 \mu \mathrm{gP} / \mathrm{L}$ (Fig. 5B). Extremely high concentrations of the total phosphorus were in the Bolshaya cove (station 15), which is likely due to flooding of this area (coastal trees and bushes were flooded during sampling). In the Monakhovo settlement (station 14), high concentration of the total phosphorus is understandable: the coast is occupied by tourist tents without the appropriate infrastructure, there is also a large number of ships at the pier.

The average concentration of silica in the coastal waters of the Chivyrkuy Bay was $0.65 \mathrm{mg} / \mathrm{L}$; an increase in its concentration of up to $0.9 \mathrm{mg} / \mathrm{L}$ was recorded 

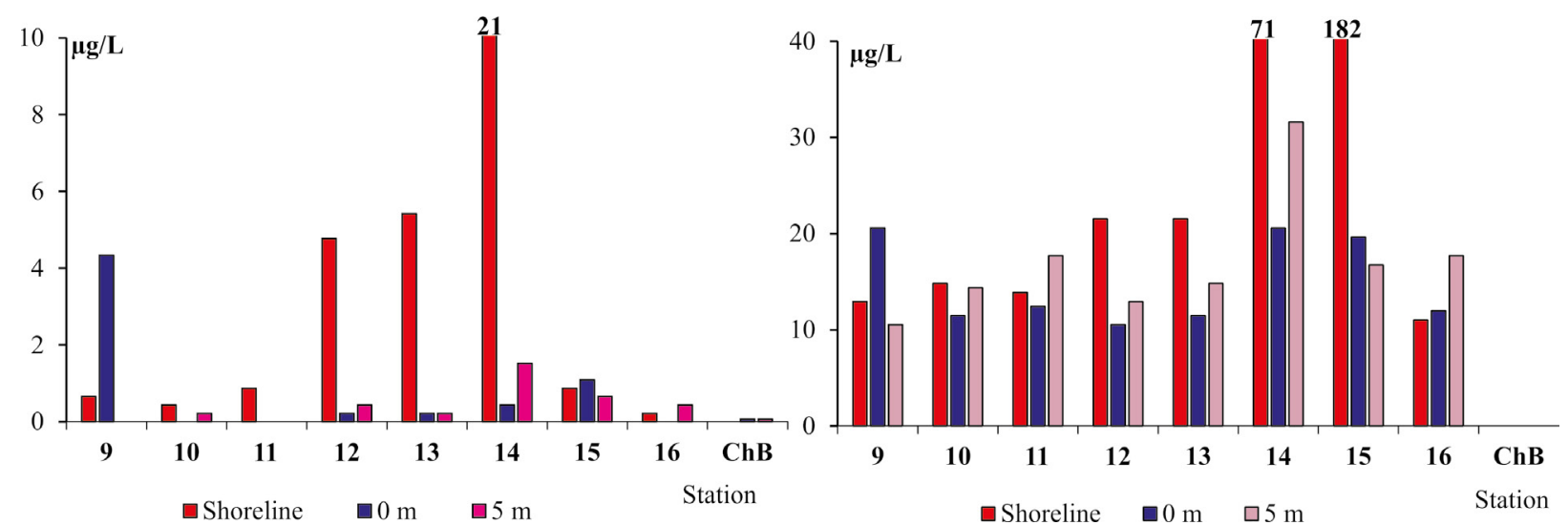

Fig. 5. Distribution of concentrations of mineral (A) and total (B) phosphorus by stations in the Chivyrkuy bay, August 2019.

in the Zmeinaya cove and the water edge of Ongokon cove (stations 10 and 11), which may be due to the influx of silica-rich groundwaters.

The concentrations of ammonium and nitrite ions both in the littoral zone and central part of the Chivyrkuy Bay were below the detection limits of the applied research methods. High ammonium ion concentrations of up to 0.010 and $0.29 \mathrm{mg} / \mathrm{L}$ with high oxygen concentration in the Monakhovo settlement indicate the faecal pollution of waters. The amount of nitrate ions in the coastal waters of the Chvyrkuy Bay, generally, does not exceed $0.1 \mathrm{mg} / \mathrm{L}$. Their maximum amount of $0.53 \mathrm{mg} / \mathrm{L}$ was recorded in the water edge near the Kurbulik settlement (station 12), which is most likely due to the proximity of the settlement with no sewage system. The influx of nutrients and organic substances from tourist campsites in the Monakhovo settlement and a sufficient warming up of the water causes the intensification of the development of algae, as evidenced by the high concentration of chlorophyll $a$ in the water edge and COD values (Fig 6A, 6B). Notably, at this station, primary production was $1.86 \mathrm{mg} / \mathrm{L}$. This is the maximum value obtained during our studies, whereas the average value of the primary production in the Chivyrkuy Bay was $0.19 \mathrm{mg} / \mathrm{L}$.

The nutrient concentrations at some stations of the littoral zone in the Chivyrkuy Bay were higher than in the background areas. It should be noted that previous studies (Tomberg et al., 2012; Vorobyovskaya et al., 2016; O'Donnell et al., 2017) showed the same problem areas, indicating the constant pollution of the coastal waters in the bay.

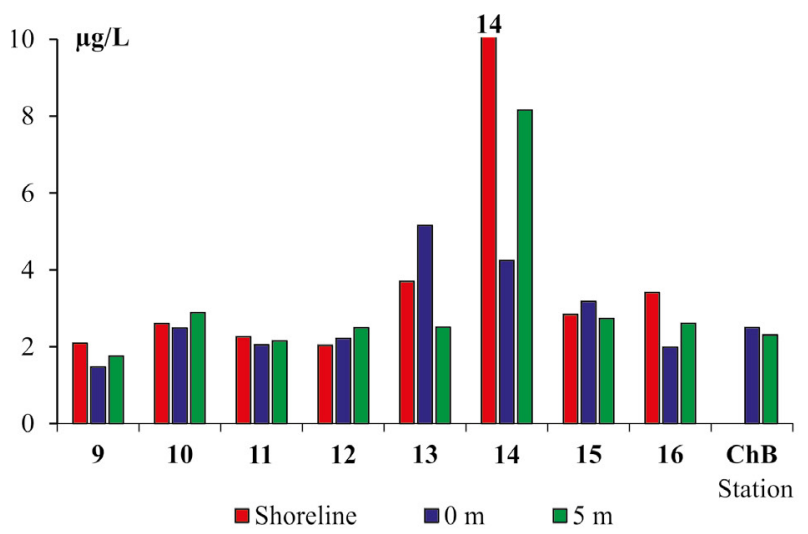

\section{Assessment of water quality in the bays}

Many methods determine the quality of water in water bodies and watercourses based on chemical indicators. The maximum permissible concentration (MPC) is mostly used to assess the water quality according to sanitation and hygiene standards (hygiene standard GN 2.1.5.1315-03, 2003; hygiene standard GN 2.1.5.2280-07, 2007; sanitary rules and norms SanPiN 2.1.5.980-00, 2000), standards for fishery use of water bodies (Prikaz Rosrybolovstva, 2010), the environmental and sanitation indicators (Oksiyuk et al., 1993) and comprehensive water pollution index (CWPI) (regulatory guide RD 52.24.643-2002, 2003). Comprehensive indicators of water quality provide a unified assessment and comparison of water purity at different sites and at different times as well as detection of substances that mainly contribute to the overall water pollution.

Among the entire set of the studied elements, hygiene standard GN 2.1.5.1315-03 (2003) normalizes mineral forms of nitrogen as well as phosphates. We identified no excess of MPCs for these elements in the waters of the bays. According to the standards for fishery use of water bodies, we also did not identify the excess of MPCs for the studied elements. Sanitary rules and norms SanPiN 2.1.5.980-00 normalize pH, BOD5 and COD. We recorded the excess of the $\mathrm{pH}$ standard for drinking and domestic water supply as well as for recreational water use in 19 of 24 water samples from the Chivyrkuy Bay and in 5 of 20 water samples from the Barguzin Bay.

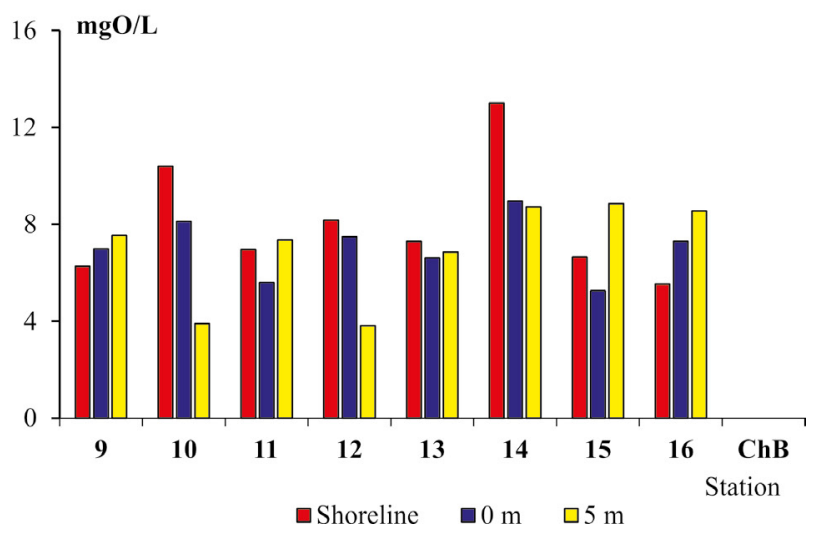

Fig. 6. Distribution of the chlorophyll $a$ concentrations (A) and COD (B) by stations in the Chivyrkuy Bay, August 2019. 
According to environmental and sanitation classification (Oksiyuk et al., 1993), the waters of the bays can be assessed as polluted to a different degree based on $\mathrm{pH}$ and oxygen saturation of water. The lower water quality is in the Chivyrkuy Bay (Fig. 7). This is due to a large number of organized and independent tourists, lack of sewage systems and discharge of domestic and waste waters from the ships near the coast. A large amount of dissolved oxygen in the water can also have a polluting effect on the water body. However, the phytoplankton development may cause high oxygen concentration in the water due to the difference in rates of oxygen removal into the atmosphere (evasion) and intensity of water saturation with oxygen resulted from photosynthesis. Indeed, a low concentration of carbon dioxide (more than 8 $\mathrm{pH}$ units), compounds of nitrogen and phosphorus as well as high chlorophyll $a$ concentration $(14.4 \mu \mathrm{g} / \mathrm{L}$ near the Monakhovo settlement) indicate the active photosynthesis in the bays, an increase in the biomass of not only phytoplankton but also phytobenthos (fouling on stones) and higher aquatic vegetation. The biomass decomposition of all algae at the end of the growth of aquatic vegetation, as well as the isolation behind the ice cover from the atmosphere, will lead to an increase in organic substances and nutrients, a decrease in oxygen and overall deterioration of water quality, which can result in disturbance of trophic links and overall degradation of the ecosystem.

To calculate CWPI, we used the data on the concentrations of mineral forms of nitrogen, mineral phosphorus, $\mathrm{COD}, \mathrm{pH}$, and oxygen saturation of water. The CWPI calculation has revealed that based on the occurrence frequency the water pollution in the Barguzin Bay is "unstable" according to the $\mathrm{pH}$ value and "typical" according to the oxygen saturation of water.

Based on the frequency of the MPC excess, the level of water pollution in the Barguzin and Chivyrkuy bays is "low" according to both the $\mathrm{pH}$ value and the oxygen saturation of water.

In general, based on CWPI, the water in the Barguzin bay belongs to the first contamination class, conditionally pure, and the water in the Chivyrkuy Bay belongs to the second contamination class, conditionally polluted.

\section{Conclusions}

Based on our measurements, the assessment of the quality of the waters in the bays during summer revealed no excess of MPCs according to sanitation and hygiene standards and standards for fishery use of water bodies. According to environmental and sanitation classification, the waters in the bays are assessed as polluted to a different degree, with the lower water quality in the Chivyrkuy Bay.

According to CWPI, the waters in the Chivyrkuy and Barguzin bays are assessed as conditionally polluted and conditionally pure, respectively. At the same time, we assume that upon the completion of the grown of

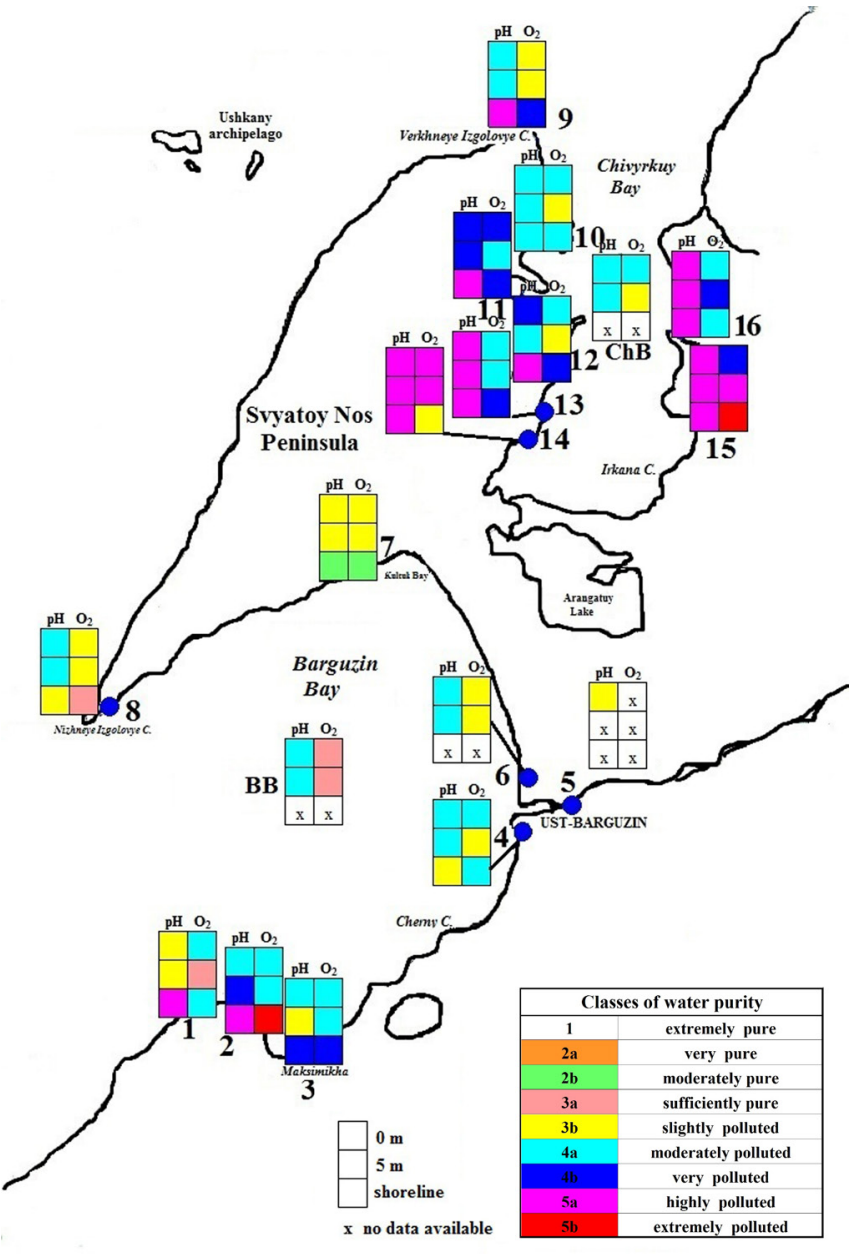

Fig. 7. Assessment of the quality of waters in the Chivyrkuy and Barguzin bays according to environmental and sanitation indicators in the summer of 2019. Colours indicate the class of water quality (Oksiyuk et al., 1993) based on $\mathrm{pH}$ (first column) and percentage of the oxygen saturation of water (second column).

the aquatic vegetation, $\mathrm{pH}$ and oxygen saturation of water will decrease, and the water quality will improve according to these indicators. Nevertheless, the decomposition of dead algae will lead to an increase in the number of nutrients and organic matter, which, in turn, will deteriorate the water quality already according to these indicators.

To improve the environmental state of the Barguzin and Chivyrkuy Bays of Lake Baikal, it is necessary to fulfil water protection measures aimed at reducing anthropogenic impact by reducing recreational and domestic pressure, constructing tourist infrastructure for existing campsites and organizing wastewater treatment systems for ships.

\section{Acknowledgements}

This study was carried out within the framework of State Tasks Nos. 0345-2020-0008 and AAAAA17-117021310142-5 and with the partial support of Russian Foundation for Basic Research and the Government of the Republic of Buryatia of the Russian Federation (Grant No. 18-45-030007) 


\section{References}

Federal environmental regulation PND F 14.1:2:4.15499. 2012. Quantitative chemical analysis of water. The method for measuring permanganate oxidation in samples of drinking, natural and waste waters by the titrimetric analysis. Moscow: Federal Service for the Supervision of Natural Resources. (in Russian)

Federal environmental regulation PND F 14.1:2:4.19003. 2007. Quantitative chemical analysis of water. Method for determination of dichromate oxidation (chemical oxygen demand) in samples of natural, drinking and waste waters by the photometric method using the Fluorat-02 liquid analyser. Moscow: Ministry of Natural Resources of the Russian Federation. (in Russian)

Hygiene standard GN 2.1.5.1315-03. 2003. The maximum permissible concentrations (MPCs) of chemicals in the water of water bodies of domestic, drinking, and cultural and domestic water use, as amended on July 13, 2017. Moscow: Ministry of Health of the Russian Federation. Russian Register of Potentially Hazardous Chemical and Biological Substances of the Ministry of Health of Russia. (in Russian)

Hygiene standard GN 2.1.5.2280-07. 2007. The maximum permissible concentrations (MPCs) of chemicals in the water of water bodies of domestic, drinking, and cultural and domestic water use. Amendments No. 1 to GN 2.1.5.1315-03. Bulletin of regulatory acts of federal executive bodies No. 50 . (in Russian)

Kravtsova L.S., Izhboldina L.A., Khanaev I.V. et al. 2012. Disturbances of the vertical zoning of green algae in the coastal part of the Listvennichnyi Gulf of Lake Baikal. Doklady Biological Sciences 448: 227-229. DOI: 10.1134/ S0012496612060026

Kravtsova L.S., Izhboldina L.A., Khanaev I.V. et al. 2014. Nearshore benthic blooms of filamentous green algae in Lake Baikal. Great Lakes Research 40: 441-448. DOI: 10.1016/j. jglr.2014.02.019

National Standard GOST 17.1.4.02-90. 2010. Water. Method of spectrophotometric determination of chlorophyll a. Moscow: Standartinform. (in Russian)

National standard GOST 18309-2014. 2015. Water. Methods for the determination of phosphorus-containing substances. Moscow: Standartinform. (in Russian)

National standard GOST 33045-2014. 2019. Water. Methods for the determination of nitrogen-containing substances. Moscow: Standartinform. (in Russian)

O’Donnell D.R., Wilburn P., Silow E.A. et al. 2017. Nitrogen and phosphorus colimitation of phytoplankton in Lake Baikal: insights from a spatial survey and nutrient enrichment experiments. Limnology and Oceanography 62: 1383-1392. DOI: 10.1002/lno.10505

Oksiyuk O.P. Zhukinsky L.P., Braginsky et al. 1993. A comprehensive environmental assessment of the quality of surface waters. Gidrobiologicheskij Zhurnal [Hydrobiological Journal] 29: 62-72. (in Russian)

Prikaz Rosrybolovstva № 20. 2010. “On the approval of water quality standards for water bodies used for fishery, including standards for maximal allowable concentrations of hazardous substances in water of water bodies used for fishery". (in Russian)

Regulatory guide RD 52.24.383-2018. 2018. Mass concentration of ammonia nitrogen in the water. Measurement technique by the photometric method in the form of indophenol blue Rostov-on-Don: Rosgydromet. (in Russian)

Regulatory guide RD 52.24.419-2005. 2004. Mass concentration of dissolved oxygen in water. Measurement technique by iodometry. Rostov-on-Don: Rosgydromet. (in Russian)

Regulatory guide RD 52.24.420-2006. 2006. Biochemical oxygen demand. Measurement technique by light and dark bottle method. Rostov-on-Don: Rosgydromet. (in Russian)

Regulatory guide RD 52.24.433-2005. 2005. Mass concentration of silica in the surface waters. Measurement technique by the photometric method in a yellow form of molybdosilicic acid. Rostov-on-Don: Rosgydromet. (in Russian)

Regulatory guide RD 52.24.495-2017. 2017. Hydrogen indicator of waters. Measurement technique by potentiometric method. Rostov-on-Don: Rosgydromet. (in Russian)

Regulatory guide RD 52.24.643-2002. 2003. Methodological guidelines. A method for a comprehensive assessment of the degree of pollution of surface waters by the hydrochemical indicators. St. Petersburg: Gidrometeoizdat. (in Russian)

Rukovodstvo po metodam gidrobiologicheskogo analiza poverkhnostnykh vod i donnykh otlozheniy [Guide to methods for hydrobiological analysis of surface water and bottom sediments]. 1983. In: Abakumov V.A. (Ed.). Leningrad: Gydrometeoizdat. (in Russian)

Sanitary rules and norms SanPiN 2.1.5.980-00. 2000. Hygienic requirements for surface water protection. Moscow: Federal Centre for State Sanitary and Epidemiological Supervision of the Ministry of Health of Russia. (in Russian)

Timoshkin O.A., Samsonov D.P., Yamamuro M. et al. 2016. Rapid ecological change in the coastal zone of Lake Baikal (East Siberia): is the site of the world's greatest freshwater biodiversity in danger? Journal of Great Lakes Research 42: 487-497. DOI: 10.1016/j.jglr.2016.02.011

Tomberg I.V., Sakirko M.V., Domysheva V.M. et al. 2012. First data on the chemical composition of interstitial waters of the splash zone of Lake Baikal. Izvestiya Irkutskogo Gosudarstvennogo Universiteta. Seriya "Biologiya. Ekologiya" [The Bulletin of Irkutsk State University. Series "Biology. Ecology"] 5: 64-74. (in Russian)

Tomberg I.V., Sinyukovich V.N., Ivanov V.G. et al. 2019. Transformation of the chemical composition of waters from the Barguzin River in the Barguzin Bay (Lake Baikal). Limnology and Freshwater Biology 4: 275-280. DOI: 10.31951/2658-3518-2019-A-4-275

Vorobyovskaya E.L., Gorshkova O.M., Ermolychev F.B. et al. 2016. The study of water pollution in the Chivyrkuy Bay of the Trans-Baikal National Park in the winter of 2016. In; International Scientific and Practical Conference «Education and Science in the XXI Century», pp. 133-137. 